\title{
THEORIZING ABOUT GLOBAL IMBALANCES: AN INEQUALITY PERSPECTIVE
}

Current account imbalances, now manifested as intensified trade wars between countries, have recently received much attention from researchers. This article reviewed this global issue from a new perspective complementary to the existing research. The study proposed a simple economic model and discovered that the current account balance is inversely proportional to the ratio of income to consumption inequality. This ratio combines all consumption smoothing schemes that depend on political interventions that can alleviate increases in income inequality. In the long run, however, current accounts could be consequently affected by a short-sighted policy.

Keywords: inequality, political manipulation, financial deregulation

JEL Classification: F41, O24

DOI: $10.15611 /$ aoe.2021.1.08

\section{INTRODUCTION}

Global current account imbalances were recently manifested as intensified U.S. trade disputes with China and other countries (Munoz, 2019). Such economic imbalances have long been a hotly debated global issue in terms of their causes and effects. The 2007-2009 worldwide financial crises were attributed to large global imbalances, among other things low interest rates, slack monetary policy, and widespread financial deregulation (Caballero et al., 2008; Blanchard and Milesi-Ferretti, 2009; Keys et al., 2010). Various explanations for U.S. current account deficits have emerged in the literature, including lower savings than real investment, global underinvestment in productive capital, and the US dollar's role as the world's reserve currency (Obstfeld and Rogoff, 2001; Bernanke, 2005; Rajan, 2010; Bluedorn and Leigh, 2011). The problem of such deficits is not limited to the U.S. but also prevails in other developed economies, especially in the major Englishspeaking countries: Australia, Canada, New Zealand, the United Kingdom (Atkinson et al., 2011, Kumhof et al., 2012). No consensus has been reached

\footnotetext{
* Faculty of Social Sciences, University of Macau, Macau, China.
} 
in the literature over the structural reasons for this problem, therefore it was necessary to revisit the issue of global imbalances amid the ongoing trade wars, as was done in this paper, through cross-country comparisons.

New advances have recently been made in accounting for the root causes of global imbalances. The deterioration of current accounts occurs in deficit economies that have also experienced a steep rise in income inequality over recent decades (Stiglitz, 2009, Sheng, 2014c, Sheng, 2021). The link between larger current account deficits and higher income inequality has been documented with long-term data from those countries and analysed by means of theoretical formulations and empirical estimation (Kumhof et al., 2012). Income inequality was also observed to have risen rapidly in surplus countries such as China and other Asian economies, but their current accounts have improved significantly since the 1997-98 Asian financial crisis. A few more recent studies have been devoted to the key issue of why higher income inequality tends to increase the savings rate in surplus economies, but decrease it in deficit countries (Li and Zou, 2004; Isacan 2010), with both of these shifts directly leading to global current account imbalances. This article examined the similarities between these deficit economies and the differences between the two sides of the imbalances. The similarities are that the lower and middle classes, suffering from stalling real earnings in the U.S. and other Organization for Economic Co-operation and Development (OECD) countries, are allowed to borrow from the rich to maintain or increase their level of consumption (Iacoviello, 2008), while the differences are that such deficit spending is basically absent in China and other Asian countries due to their financial market imperfections (Caballero et al., 2008).

One can indicate two distinct countries, namely, those pursuing finance-led economic growth models such as the U.S. and the U.K., and export-led economic growth models such as China and India (Ranciere et al. 2012). For export-led countries, high production capacity created by relatively low-cost labour (mainly from the middle and the lower classes) is the main driver of increased exported quantities and thus boosts the national surplus. However, this wealth created by the middle and lower classes is mainly concentrated among a few top earners, while the incomes (mainly labour income) of the middle and lower classes remain unchanged or grow at a much slower rate than those of the upper class, which in the long term leads to greater income inequality. Moreover, due to undeveloped financial mechanisms, the income sources of the middle and lower classes are very limited, which reduces their consumption capacity and therefore constrains social consumption demand. In this case, consumption inequality reflects income inequality (Binkai 2012, Sheng 2010). Yet, when the domestic consumption level of the upper class 
reaches its upper limit while the consumption level of the middle and lower classes remains at a stable level, consumption inequality remains unchanged. However, as the upper classes obtain dividend income from financial investments in other countries with greater financial liberalization, income inequality continues to expand, while consumption inequality remains at a constant level. In this case, consumption inequality is inconsistent with income inequality (Lin et al., 2010).

There is still much room for improvement in research on global imbalances related to income inequality. Political interventions in deficit countries play a key role in fostering such external imbalances by avoiding dealing with the sources of inequality directly, but rather temporarily mitigate its consequences for the living standards of the lower and middle classes through financial liberalization (Rajan, 2010). While such mitigating effects of liberalization have been examined in empirical studies (Perugini et al., 2015, Sheng, 2014b), no theoretical framework has been provided in the literature to explicitly analyse the role of such political interventions in the resultant worsening current accounts in line with rising income inequality. Financial liberalization successfully boosts the living standards of the lower and middle classes via consumer credit despite their stagnating real incomes, with such credit-fuelled consumption booms financed in a very large part by foreign savings via capital inflows. The resulting situation observed in deficit countries is that consumption inequality remains relatively stable even given a rapid hike in income inequality (Angel and Bittschi, 2018; Sheng, 2014). Such a widening divergence between income and consumption inequality signals domestic debt accumulation and aggregate demand expansion, which lead to current account deteriorations and even to severe financial crises (Kumhof et al., 2015; Sheng, 2014a). However, there is a dearth of research on the implications of this inequality divergence for global imbalances.

This paper provides an alternative theory and additional evidence as a supplementary analysis to the literature on global imbalances. Faced with rising income inequality which is bad for the lower classes, politicians must prevent the resulting drop in the living standards due to their voting power. However, it is politically incorrect to finance increased social welfare for the lower classes through higher taxes on the upper classes, as these are a main source of election donations (Hacker and Pierson, 2010). Financial liberalization therefore arises as an innovative policy by allowing the poor to borrow from the rich. Everyone may become better off since the upper classes can reap a return on their lending, while the lower classes may sustain their living standards (Volscho and Kelly, 2012). The end result must be a widening gap between income and consumption inequality. This theoretical analysis proposes 
a simple new model to identify the effects of this gap on current account imbalances and the role of political interventions in its amplification effect. Although consumption is harder to measure than income, recently a growing effort has been made to address the distinction between income and consumption inequality as consumption is more relevant to the wellbeing of the lower and middle classes (Attanasio and Pistaferri, 2016). While the distribution of income is affected by tax and transfer policies, the evolution of consumption hinges on saving/borrowing behaviour and other smoothing schemes (Krueger and Perri, 2006; Blundell et al., 2008). Thus it seems more reasonable to look into current account imbalances through comparisons between income and consumption inequality, as done in this article, rather than address income inequality alone. The concomitant occurrence of economic inequality, global imbalances, and financial crises may be due to coincidence and caused by certain common factors (Obstfeld and Rogoff, 2009; Krugman, 2010; Sheng 2012).

\section{LITERATURE REVIEW}

A brief introduction of the existing studies that are relevant to this matter follows. First, to begin with an old problem of income inequality, which began to appear again at the beginning of the 1980s. To date, researchers have paid a lot of attention to this issue, and many studies aimed to identify the driving forces behind the observed changes in income distribution (Blanchard and Giavazzi, 2003; Card et al., 2004; Lemieux et al., 2009; Roberts, 2010), while others concentrated on measuring long-term changes in income inequality and assessing their adverse economic impacts (Piketty and Saez, 2003; Krueger and Perri, 2006; Berg and Ostry, 2011). Obviously, increasing household indebtedness and the consequent financial vulnerability are due to growing income inequality (Iacoviello, 2008; Rajan, 2010; Reich, 2010; Kumhof et al., 2015). In addition, higher income inequality is associated with more household borrowing from abroad and with increasing global current account imbalances (Broer, 2010; Lebarz, 2011; Kumhof et al., 2012). In major English-speaking countries, these problems are observed to be more pervasive, however in some European countries they are less severe and are just newly emerging (Atkinson et al., 2011; Sheng, 2011).

Economic inequality occurs along multiple dimensions, and recently, researchers' focus has turned to consumption inequality. Compared with income inequality, consumption inequality is probably more crucial because income is only a part of utility, which is produced by consumption. (Attanasio and Pistaferri, 2016). Saving, borrowing, insurance, and (private and public) transfers can smooth consumption spending. The distribution of expenditure 
is less broad and more volatile than that of income in the U.S., so that the U.S. ratio of income to consumption inequality is greater than one and even exhibits an upward trend over time in some datasets (Heathcote et al., 2010; Aguiar and Bils, 2015; Sheng, 2021). Similarly, consumption inequality has remained fairly stable and is significantly lower than income inequality in most European countries, where some kind of convergence is observable for consumption inequality, but not for income inequality, over a long sample period (Angel and Bittschi, 2018). Although consumption and income present different dynamics in their distributions, the literature is still unclear regarding their differing implications for current accounts or financial risks. Moreover, research has not found any formal work that tackles the potential link between global current account imbalances and differing cross-country ratios of income to consumption inequality. This issue is explained here, providing a significant contribution to the literature.

The relationship between income and consumption inequality in the U.S. is similar to that in some European states but different from that in China and other Asian economies. This research elucidates global imbalances and financial crises since such a relationship involves more smoothing schemes (e.g. saving, insurance, and transfers) rather than just household leverage. It is observed that in China, income inequality can be traced closely by consumption inequality (Cai et al., 2010; Ding and He, 2015; Sheng, 2015), however this connection becomes much weaker in the U.S. (Meyer and Sullivan, 2013). As the most representative exampleof a deficit economy, the U.S. obviously has a stronger consumption smoothing ability than China, considered the most representative surplus economy. This fact has an important impact on global imbalances (Lardy, 2006). With high income inequality in China, the extensive savings of the upper class can neither be borrowed from for consumption by the poor nor can they be used for large-scale infrastructure construction. Surpluses of savings over investment corresponding to high consumption inequality must be converted into trade surpluses, and capital surpluses must be recycled because of underdeveloped domestic financial markets (Caballero et al., 2008). In the U.S., where income inequality is high, the upper classes can lend a portion of their rising incomes and intermediating foreign savings to domestic workers, who use such credit to maintain or improve their standard of living (Broer, 2010). Such deficit spending, while effectively preventing greater inequality in consumption, must lead to a decline in the overall savings rate, which in turn leads to a decline in the current account balance (Brown, 2008). From this new perspective, this study should complement the existing research because it produces deeper insights into the problem of global imbalances. 


\section{THEORETICAL DISCUSSION}

A simple theory is proposed below to show how current account imbalances are affected by political interventions that are meant to support the living standards of those who possess majority voting power but suffer from stagnating real incomes (Rajan, 2010). Lower inequality in consumption than in income is modelled as an outcome of such interventions. Financial liberalization policies allow the lower classes to borrow from the upper classes through consumer credit (Bertrand and Morse, 2012). The upper classes also fund a substantial part of their increased domestic lending by intermediating foreign savings. These practices turn out to be effective in reducing consumption inequality even in the face of rising income inequality. However, such credit-fuelled consumption depresses national savings, which fall below the domestic needs for real investment, thus putting downward pressure on current accounts (Kumhof et al., 2012). This model is analytically tractable for generating comparative statics, and therefore there is no need to derive numerical solutions through calibrated simulation.

Consider domestic lending $D_{d}$ by top income group $T$ to bottom income group $B$. National income $Y$ is distributed to group $T$, denoted $Y_{T}$, and to group $B$, denoted $Y_{B}$. Consumption amounts to $C_{T}$ for group $T$ and to $C_{B}$ for group $B$, which may borrow for consumption due to stagnating real incomes. Spending propensity is defined as $\alpha_{T}=C_{T} / Y_{T}$ for group $T$ as usual but $\alpha_{B}=C_{B} /\left(Y_{B}+D\right)$ for group $B$ due to deficit spending, where $D$ is the total debt of group $\mathrm{B}$ borrowed from group T. Foreign resources are mainly introduced by group $T\left(D_{d}\right)$ and the government $\left(D_{f}\right)$ through flexible domestic financial and monetary policies. Group $T$ 's income consists of its dividend income derived from financial assets, its lending to Group $B\left(D_{d}\right)$ as well as the corresponding lending interest income, while group $B$ 's income includes its labour wages and debts from group $T\left(D_{d}\right)$, as well as the government $\left(D_{f}\right)$. The study defined $\beta_{T}=D_{d} Y_{T}$ as the lending ratio of group $T, \beta_{B}=D / Y_{B}$ as the debt ratio of group $B$, and $\lambda=D / D_{d}(>1)$ as a proxy for the availability of foreign financing. Consumption inequality is proxied by $C_{T} / C_{B}$ or $C_{T} / C$ and income inequality by $Y_{T} / Y_{B}$ or $Y_{T} / Y$ in the spirit of post-Keynesian models for the sake of concise aggregate analysis.

Proposition 1: The savings rate decreases with higher income inequality when consumer credit is available.

Putting together the above descriptions, one derives gap $X\left(X=Y_{T} / Y_{B}-C_{T} / C_{B}\right)$ between income and consumption inequality and ratio $Z(Z=C A B / Y=$ $I-I / Y-C / Y)$ of the current account balance $C A B$ to aggregate income $Y$ : 


$$
\begin{gathered}
X=\xi \frac{Y_{T}}{Y_{B}} \\
Z=\rho-\zeta \frac{Y_{T}}{Y}
\end{gathered}
$$

where $\xi=\left[\left(1-\alpha_{T} / \alpha_{B}\right)+\beta_{B}\right] /\left(1+\beta_{B}\right), \rho=1-I / Y-\alpha_{B}, \zeta=\alpha_{T}-\left(1-\lambda \beta_{T}\right) \alpha_{B}$, and $I$ is real investment, with the national income account used to derive the expression for $C A B / Y$. Note that $\xi>0$ since $\alpha_{T}<\alpha_{B}$ is assumed as usual to reflect behavioural differences between the two income groups, i.e. the spending propensity of the upper class with growing incomes is lower than that of the lower classes with stagnating wages. Additionally, note that $\zeta>0$ if $\beta_{T}>\left(1-\alpha_{T} / \alpha_{B}\right) / \lambda$, i.e. higher income inequality increases the consumption ratio or decreases the savings rate $s=\left(S_{T}+S_{B}\right) / Y=1-C / Y+D_{f}$ if domestic lending is high enough, with this condition weakened significantly by the greater opportunity for foreign financing of consumer credit (as $\lambda \uparrow$ ). It then follows that $\rho<0$ under $\alpha_{T}<C / Y<\alpha_{B}$, as is likely to be true in practice (Dynan et al., 2004). When $C / Y>1$, then $1-C / Y<0$, which means that total consumption exceeds total savings. This situation is always accompanied by fiscal deficits and trade deficits. The $\mathrm{CAB}$ indicates the sum of the balance of a country's international monetary transactions during a certain period, which consists of its net trade in goods and services, net earnings on cross-border investments, and net transfer payments (OECD, 2020).

Three important observations can be derived from Equations (1) and (2). First, the gap between income and consumption inequality increases with higher levels of household indebtedness, as in the U.S., since $\partial \xi / \partial \beta_{B}>0$ (Brown, 2008). Second, the link between the savings rate and income inequality may be positive under liquidity constraints or negative under consumer credit availability. In the latter case, consumption spending is constrained not by disposable income but by available liquidity, as in the U.S. (Gu et al., 2015). Third, the negative link can be further strengthened through capital inflows, as domestic spending is no longer constrained by national income but by foreign savings (Kumhof et al., 2012).

Proposition 2: Aggressive financial liberalization may contribute to a greater gap between consumption and income inequality, which may eventually lead to worse current account imbalances.

Putting together the two expressions in Equations (1) and (2) yields a linear equation that connects ratio $Z$ of the current account balance to GDP with gap $X$ between income and consumption inequality: $Z=\rho-(\zeta / \zeta) X$, with income 
inequality proxied by $Y_{T} / Y_{B}$ for convenience. As a constraint condition for policy optimization, this equation characterizes the opportunity curve for various objective tradeoffs between income-consumption inequality gaps and current account imbalances, where $\zeta / \xi$ is the marginal rate of transformation from a wider gap to a larger imbalance.

Faced with higher income inequality, policy-makers make a subjective tradeoff between lowering consumption inequality and controlling external imbalances. The policy goal is achieved through consumer credit (hinging on $\beta_{T}$ ) and capital flows (reflected by $\lambda$ ). The policy-maker minimizes the deviation between the actual and targeted levels of two key economic variables $(X, Z): \min \gamma=\tau_{1}(X-h)^{2}+\tau_{2}(Z-k)^{2}$, where the policy target levels are indicated by $(h, k)$ and the decision weights are denoted by $\left(\tau_{1}, \tau_{2}\right)$. Note that $\tau_{1}+\tau_{2}=1$ with $\tau_{1}>0$ and $\tau_{2}>0$. It is likely that $\tau_{1}>\tau_{2}$ in deficit countries, as they care strongly about living standards of lower and middle class households, whereas the reverse is true in surplus countries, as they attach great importance to trade expansion and growth performance (Rajan, 2010; Reich, 2010). The policy objective function can be expressed in the form of a standard ellipse equation (for a typical indifference curve): $(X-h)^{2} / a^{2}+(Z-k)^{2} / b^{2}=1$, where $a^{2}=\gamma / \tau_{1}$, $b^{2}=\gamma / \tau_{2}$, and the marginal rate of substitution is $-\tau_{1}(X-h) /\left[\tau_{2}(Z-k)\right]$. The policy minimization of $\gamma$ is equivalent to determining the smallest ellipse with the shortest focal length and the same slope as the original ellipse representing the actual levels that is tangent to the opportunity curve. The loss function for the policy intervention is specified as follows:

$$
\begin{gathered}
\gamma=\tau_{1}(X-h)^{2}+\tau_{2}(Z-k)^{2}, \\
\text { s.t. } Z=\rho-(\zeta / \xi) X .
\end{gathered}
$$

The closed-form solution to the problem given by Equations (3) and (4) is derived below:

$$
\begin{array}{r}
X^{*}=\frac{\frac{\varsigma}{\xi}(\rho-k)+\frac{\tau_{1}}{\tau_{2}} h}{\frac{\tau_{1}}{\tau_{2}}+\left(\frac{\varsigma}{\xi}\right)^{2}} \\
Z^{*}=\frac{\frac{\varsigma}{\xi}\left(\frac{\varsigma}{\xi} k-\frac{\tau_{1}}{\tau_{2}} h\right)+\frac{\tau_{1}}{\tau_{2}} \rho}{\frac{\tau_{1}}{\tau_{2}}+\left(\frac{\varsigma}{\xi}\right)^{2}}
\end{array}
$$


The comparative statics analysis is performed by differentiating Equations (5) and (6) with respect to the underlying parameters $\left(\tau, \beta_{T}, \lambda\right)$, where $\tau=\tau_{1} / \tau_{2}$ is the relative weight for gap $X^{*}$ between income and consumption inequality vis-à-vis the current account imbalances $Z^{*}$.

As shown in Equations (5) and (6), current account imbalances vary endogenously with the link between income and consumption inequality due to the policy interventions that allow for consumer credit and capital flows. It is easy to show that $\partial X^{*} / \partial \tau>0$ and $\partial Z^{*} / \partial \tau<0$ if $\rho-k<(\zeta / \zeta) h$. This condition is likely to hold since $\rho<0$ and $(\zeta / \xi) h>0$. Additionally, although maintaining surpluses and deficits is often a means for countries at different stages of development to boost their competitiveness and improve their external positions, if the imbalances cannot be controlled to the proper extent, over indebted households in deficit countries will find it difficult to continue to obtain credit when their income is insufficient to repay their debts; additionally, the surplus economies' overseas lending or their rapid growth may also be susceptible to the impact of sudden changes in capital flows.

\section{CONCLUSION}

This paper revisits the most pressing issue of our age, namely global current account imbalances manifested as a bitter trade war between the U.S. and its major trading partners (including China and some European countries). The article addresses this issue from a new perspective different from that of previous studies, which involves the fundamental link between income and consumption inequality. This link is systematically similar in deficit economies (especially in English-speaking countries) but significantly different between deficit and surplus economies, especially between the U.S. and China (Ranciere et al., 2012; Sheng, 2021).

In the presented theoretical model, the disjuncture between consumption and income inequality occurs in deficit countries as an outcome of their widespread consumer credit and other smoothing schemes that are made possible by policies of financial liberalization. As a result, current account deficits appear endogenously in response to higher levels of household indebtedness under rising income inequality, and reckless domestic debt is financed partly by ample foreign savings. Clearly, the ratio of income to consumption inequality moves in line with the ratio of current account deficits to aggregate income. Both ratios are determined by politicians' tradeoff between controlling current account deficits and preventing a consumption drop among the lower and middle classes through financial liberalization. This model may be the first study in the literature to explicitly address the role of 
policy interventions and the evolutionary trends of both ratios. The authors found that more aggressive policy leads to a lower level of consumption inequality and a larger deficit in the current account through lower savings rates, higher domestic indebtedness, and increased foreign financing.

Policy implications can be derived from the main results obtained in this study. The OECD experience of artificially depressing consumption inequality through financial liberalization shows that this policy can only buy time but may lead to trouble with debt problems and external imbalances later (Kumhof et al., 2012; Sheng, 2015). Surplus countries should not follow such a shortsighted policy and should avoid the accumulation of domestic indebtedness and the risk of financial crises. In the long run, one cannot avoid dealing with the income inequality problem itself directly, in both deficit and surplus countries. Reducing income inequality, albeit fraught with difficulties, can be achieved with sufficiently strong determination. There are multiple options that could be effective for problem solving if supported by political interventions. First, reindustrialisation should be pursued via various tax credits in deficit countries to increase exports and reduce imports, while the financialisation of their economies must be restrained through sufficiently high taxes. Second, tightened regulations may be needed in those countries to improve their current accounts by discouraging debt-financed profligacy and encouraging savings behaviour. Third, wage rates for the working class are too low relative to their labour productivity in surplus countries. Increasing wages can reduce both income and consumption inequality while raising aggregate demand and causing domestic growth to rely less on foreign markets. Fourth, a sufficient amount of public revenue must be spent on welfare programs for populations in countries with weak social security programs. This can reduce precautionary savings as well as public savings, thereby lowering their current account surpluses.

\section{REFERENCES}

Adam, A., Katsimi, M., Moutos, T., Inequality and the import demand function, "Oxford Economic Papers", No. 64(4), pp. 675-701. https://doi.org/10.1093/oep/gpr050, 2012.

Aguiar, M., Bils, M., Has consumption inequality mirrored income inequality?, "American Economic Review", No. 105(9), pp. 2725-2756, 2015.

Angel, S., Bittschi, B., An integrated view on trends in consumption and income inequality in Europe over the last two decades. Presented at the 35th IARIW General Conference, Copenhagen, Denmark 2018.

Atkinson, A., Piketty, T., Saez, E., Top incomes in the long run of history, "Journal of Economic Literature", No. 49, pp. 3-71, 2011. 
Attanasio, O., Pistaferri, L., Consumption inequality, "Journal of Economic Perspectives", No. 30(2), pp. 1-27, 2016.

Berg, A., Ostry, J., Inequality and unsustainable growth: Two sides of the same coin? Staff Discussion Note SDN/11/08, IMF, 2011.

Bernanke, B., The global savings glut and the US current account deficit. Sandridge Lecture, Virginia Association of Economics, 2005.

Bertrand, M., Morse, A., Trickle-down consumption. Working Paper, Chicago Booth School of Business, 2012.

Binkai, C., Income Inequality and Consumption Demand: Theory and Evidence from China [J], "Nankai Economic Studies", No. 1, 2012.

Blanchard, O., Giavazzi, F., Macroeconomic effects of regulation and deregulation in goods and labor markets, "Quarterly Journal of Economics", No. 118(3), pp. 879-907, 2003.

Blanchard, O., Milesi-Ferretti, G. M., Global imbalances: In midstream?, "Staff Position Note", IMF, 2009.

Bluedorn, J., Leigh, D., Revisiting the twin deficits hypothesis: The effect of fiscal consolidation on the current account, "IMF Economic Review", No. 59(4), pp. 582-602, 2011.

Blundell, R., Pistaferri, L., Preston, I., Consumption inequality and partial insurance, "American Economic Review”, No. 98(5), pp. 1887-1921. doi:10.1257/aer.98.5.1887, 2008.

Broer, T., Domestic or global imbalances? Rising inequality and the fall in the US current account. Working Paper, European University Institute, Florence, Italy, 2010.

Brown, C., Inequality, consumer credit and the saving puzzle [in:] Sawyer, M., Cheltenham, C. (eds.) New Directions in Modern Economics. Edwards Elgar Publishing Ltd., UK, 2008.

Caballero, R., Farhi, E., Gourinchas, P. O., An equilibrium model of global imbalances and low interest rates, "American Economic Review”, No. 98(1), pp. 358-393, 2008.

Cai, H., Chen, Y., Zhou, L. A., Income and consumption inequality in urban China: 1992-2003. "Economic Development and Cultural Change", No. 58(3), 385-413. doi:10.1086/650423, 2010.

Card, D., Lemieux, T., Riddell, D., Unions and wage inequality, "Journal of Labor Market Research", No. 25(4), pp. 520-562, 2004.

Ding, H. Y., He, H., A tale of transition: An empirical analysis of economic inequality in urban China, 1986-2009. Working Paper, Shanghai University of Finance and Economics, China, 2015.

Dynan, K. E., Skinner, J., Zeldes, S. P., Do the rich save more?, "Journal of Political Economy”, No. 112, pp. 397-444, 2004.

Frankel, J., Do globalisation and world trade fuel inequality? "Guardian”, https://www.theguardian. com/business/2018/jan/02/do-globalisation-and-world-trade-fuel-inequality, 2018.

Greene, W. H., Econometric Analysis. $7^{\text {th }}$ Ed. Boston, Prentice Hall, NJ, 2012.

Hacker, J., Pierson, P., Winner-Take-All Politics. Simon \& Schuster, New York 2010.

Heathcote, J., Perri, F., Violante, G. L., Unequal we stand: An empirical analysis of economic inequality in the United States: 1967-2006, "Review of Economic Dynamics", No. 13(1), pp. 15-51, 2010.

Iacoviello, M., Household debt and income inequality, 1963-2003, "Journal of Money, Credit and Banking”, No. 40(5), pp. 929-965, 2008. 
Isacan, T. B., Aggregate saving and income inequality: What are the links?, Working Paper, Dalhousie University, Halifax, Canada, 2010.

Keys, B. J., Mukherjee, T., Seru, A., Vig, V., Did securitization lead to lax screening? Evidence from subprime loans, "Quarterly Journal of Economics”, No. 125(1), pp. 307-362, 2010.

Krueger, D., Perri, F., Does income inequality lead to consumption inequality? Evidence and theory, "Review of Economic Studies", No. 73(1), pp. 163-193, 2006.

Krugman, P., Inequality and crises. New York Times blog The Conscience of a Liberal, June. http://krugman.blogs.nytimes.com/2010/06/28/inequality-and-crises/, 2010.

Kumhof, M., Lebarz, C., Rancière, R., Richter, A. W., Throckmorton, N. A., Income inequality and current account imbalances. Working Paper WP/12/08, IMF, 2012.

Kumhof, M., Ranciere, R., Winant, P., Inequality, leverage, and crises, “American Economic Review", No. 105(3), pp. 1217-1245, 2015.

Lardy, N. R., China: Toward a consumption-driven growth path, "Policy Briefs in International Economics", No. PB06-6. Institute for International Economics, Washington, DC, 2006.

Lebarz, C., Inequalities, household leverage and global imbalances. Master's Thesis, Paris School of Economics, 2011.

Lemieux, T., MacLeod, B., Parent, D., Performance pay and wage inequality, "Quarterly Journal of Economics", No. 124(1), pp. 1-49, 2009.

Li, H., Zou, H. F., Savings and income distribution, "Annals of Economics and Finance", No. 5(2), pp. 245-270, 2004.

Lin, J. Y., Dinh, H. T., Im, F., US-China external imbalance and the global financial crisis, "China Economic Journal", No. 3(1), pp. 1-24, 2010.

Meyer, B. D., Sullivan, J. X., Consumption and income inequality and the great recession, “American Economic Review”, No. 103(3), 178-183. doi:10.1257/aer.103.3.178, 2013.

Munoz, E., Trump's trade war cost U.S. economy $\$ 7.8$ billion in 2018. Business News, Reuters, March 16, 2019. https://www.reuters.com/article/us-usa-trade/trumps-trade-war-cost-u-seconomy-7-8-billion-in-2018-study-idUSKCN1QW2PO

Obstfeld, M., Rogoff, K., The six major puzzles in international macroeconomics: Is there a common cause?, "NBER Macroeconomics Annual", No. 15, pp. 339-412, 2001.

Obstfeld, M., Rogoff, K., Global imbalances and the financial crisis: Products of common causes, Working Paper, UC Berkeley and Harvard University, 2009.

OECD, Current account balance. (Accessed on 08 July 2020).

Pavcnik, N., The impact of trade on inequality in developing countries, Working Paper No. 23878, NBER, 2017.

Perugini, C., Holscher, J., Collie, S., Inequality, credit expansion and financial crises, "Cambridge Journal of Economics", pp. 1-31, 2015.

Piketty, T., Saez, E., Income inequality in the United States, 1913-1998, "Quarterly Journal of Economics", No. 118, pp. 1-39, 2003.

Rajan, R., Fault Lines: How Hidden Fractures Still Threaten the World Economy. Princeton University Press, Princeton 2010.

Reich, R., Aftershock: The Next Economy and America's Future. Random House, New York 2010.

Roberts, P. C., How the Economy Was Lost. AK Press 2010. 
Sheng, L., Growth-Volatility Tradeoff in the Face of Financial Openness: A Perspective of Developing Economies, "Cambridge Review of International Affairs", No. 23(4), pp. 209-222, 2010.

Sheng, L., Theorizing Free Capital Mobility: A Perspective on Developing Economies, "Review of International Studies", No. 37(5), pp. 2519-2534, 2011.

Sheng, L., Dealing with Financial Risks of International Flows: A Theoretical Framework, "Cambridge Review of International Affairs", No. 25(3), pp. 463-474, 2012.

Sheng, L., Income Inequality, Financial System, and Global Imbalances: A Theoretical Consideration, "Global Policy", No. 5(3), pp. 311-320, 2014a.

Sheng, L., Economic Structure, Cost Outsourcing, and Global Imbalances, "Journal of Australian Political Economy", No. 74, pp. 81-94, 2014 b.

Sheng, L., Capital Controls and International Development: A Theoretical Reconsideration, "Global Policy", No. 5(1), pp. 114-120, 2014c.

Sheng, L., Theorizing Global Imbalances: A Perspective of Savings and Inequality, "Cambridge Review of International Affairs", No. 28(2), pp. 191-204, 2015.

Sheng, L., Explaining US-China Economic Imbalances: A Social Perspective, "Cambridge Review of International Affairs", No. 29(3), pp. 1097-1111, 2016.

Sheng, L., Nascimento, D. F., Love and Trade War: China and the US in Historical Context. Palgrave Macmillan, London 2021.

Stiglitz, J. E., The global crisis, social protection and jobs, "International Labor Review", No. 148, pp. 1-13, 2009.

Volscho, T. W., Kelly, N. J., The rise of the super-rich: Power resources, taxes, financial markets, and the dynamics of the top 1 percent, 1949-2008, "American Sociological Review", No. 77(5), pp. 679-699, 2012.

Urata, S., Narjoko, D. A., International trade and inequality. Working Paper 675, Asian Development Bank Institute, Tokyo, https:/www.adb.org/publications/international-tradeand-inequality, 2017.

Zweimüller, J., Egger, P., Föllmi, R., Economic inequality and international trade, "Sinergia Project", University of Zurich and University of St. Gallen, 2018. https://www.econ.uzh.ch/ en/people/faculty/zweimueller/projects/eiit.html 